\title{
Influencing epigenetic information with a hydrolytically stable carbocyclic 5-aza-2'-deoxycytidine
}

\author{
Thomas M. Wildenhof, ${ }^{[a]}$ Sarah Schiffers, ${ }^{[a]}$ Franziska R. Traube, ${ }^{\left[{ }^{[a]}\right.}$ Peter Mayer ${ }^{[a]}$ and Thomas Carell ${ }^{\star[a]}$ \\ [a] Department of Chemistry, Ludwig-Maximilians-Universität München, Butenandtstrasse 5-13, Munich, \\ Germany \\ * address correspondence to: Thomas.carell@Imu.de
}

This article was first published online on 17.06.2019 in Angewandte Chemie International Edition under DOI 10.1002/anie.201904794

\section{Dedicated to Prof. J. Rebek, Jr. on the occasion of his $75^{\text {th }}$ birthday}

\begin{abstract}
Aza-2'-deoxycytidine (AzadC) is an antimetabolite in clinical use, which reduces the level of the epigenetic modification 5-methyl-2'-deoxycytidine ( $m d C$ ). AzadC is incorporated into the genome of proliferating cells, where it inhibits the DNA methyltransferases (DNMTs) in a suicide process leading to a reduction of $m d C$. The loss of $m d C$, which is a transcriptional silencer in promoters, leads to the reactivation of genes including tumor suppressor genes, which elicits a beneficial effect. The problem associated with AzadC is that the compound is hydrolytically unstable. It decomposes during treatment to a variety of poorly characterized hydrolysis products. After its incorporation into the genome, this hydrolytic instability generates abasic sites. It is consequently difficult to dissect if the activity of the compound is caused by DNMT inhibition or more generally by DNA lesion formation. We now discovered that a disarmed version of $A z a d C$, in which the ribose oxygen was replaced by a $\mathrm{CH}_{2}$-group, is surprisingly stable under a variety of $\mathrm{pH}$ values while keeping the epigenetic activity against the DNMTs.
\end{abstract}

5-Aza-2'-deoxycytidine (decitabine, AzadC) is a nucleoside analogue that is able to manipulate epigenetic information. ${ }^{[1-5]}$ Epigenetic information in DNA is associated with the formation of 5-methyl2'-deoxycytidine $(\mathrm{mdC})$ from 2'-deoxycytidine $(\mathrm{dC})$ with the help of DNA methyltransferases (DNMTs) and S-adenosylmethionine (SAM) as the methylating cofactor. ${ }^{[6-7,4]}$ Methylation of $\mathrm{dC}$ to $\mathrm{mdC}$ in promoter regions is typically associated with transcriptional silencing of genes. ${ }^{[8-9]} \mathrm{AzadC}$ is a prodrug that is inside cells converted into the corresponding active triphosphate and subsequently incorporated into the genome during cell division. The mode of action of AzadC involves reaction of its electrophilic C6 positions with a DNMT active site thiol nucleophile (Fig. 1a). ${ }^{[10-11]}$ This generates a covalent intermediate that is methylated by the SAM cofactor as depicted in Fig 1a. Due to the $\mathrm{N}$-atom at position 5 of the triazine heterocycle, the final $\beta$-elimination reaction, which would usually release mdC from the DNMT enzyme, is not possible anymore. The consequence is the formation of a covalent DNA-DNMT crosslink. As a result of administering AzadC, a large drop of the mdC levels (hypomethylating effect) is observed, which leads to the reactivation of silenced tumor suppressor genes in cancer cells. ${ }^{[1]}$ This epigenetic effect is hoped to re-differentiate cancer cells back into normally proliferating cells. AzadC is currently in use as one of the first pharmaceuticals that operates at the epigenetic level for the treatment of myelodysplastic syndromes (MDS ${ }^{[2]}$ and for acute myeloid leukemia $(A M L)^{[4]}$. Clinically, it is administered in several cycles, with each cycle involving one week of treatment and three weeks of pausing.

The problem associated with AzadC is that the compound hydrolyses in aqueous solution following the path depicted in Fig. 1b. This hydrolysis compromises the activity of AzadC, particularly over the long treatment times. In order to circumvent this problem, it is necessary to generate an AzadC compound that can demethylate (and hence react with an S-nucleophile), while hydrolysis (reaction with an Onucleophile) should be blocked. Such a compound may allow to dissect how demethylation and lesion 
formation contribute to the anti-cancer activity, which is an information needed for the design of new epigenetically acting antimetabolites.

Here, we report that replacing the oxygen of the ribose by a $\mathrm{CH}_{2}$-group has a surprisingly large remote effect on the reactivity of the heterocycle. The created carbocyclic version of AzadC (cAzadC, 1) still inhibits DNMTs but is hydrolytically stable (Fig. 1c).

a)

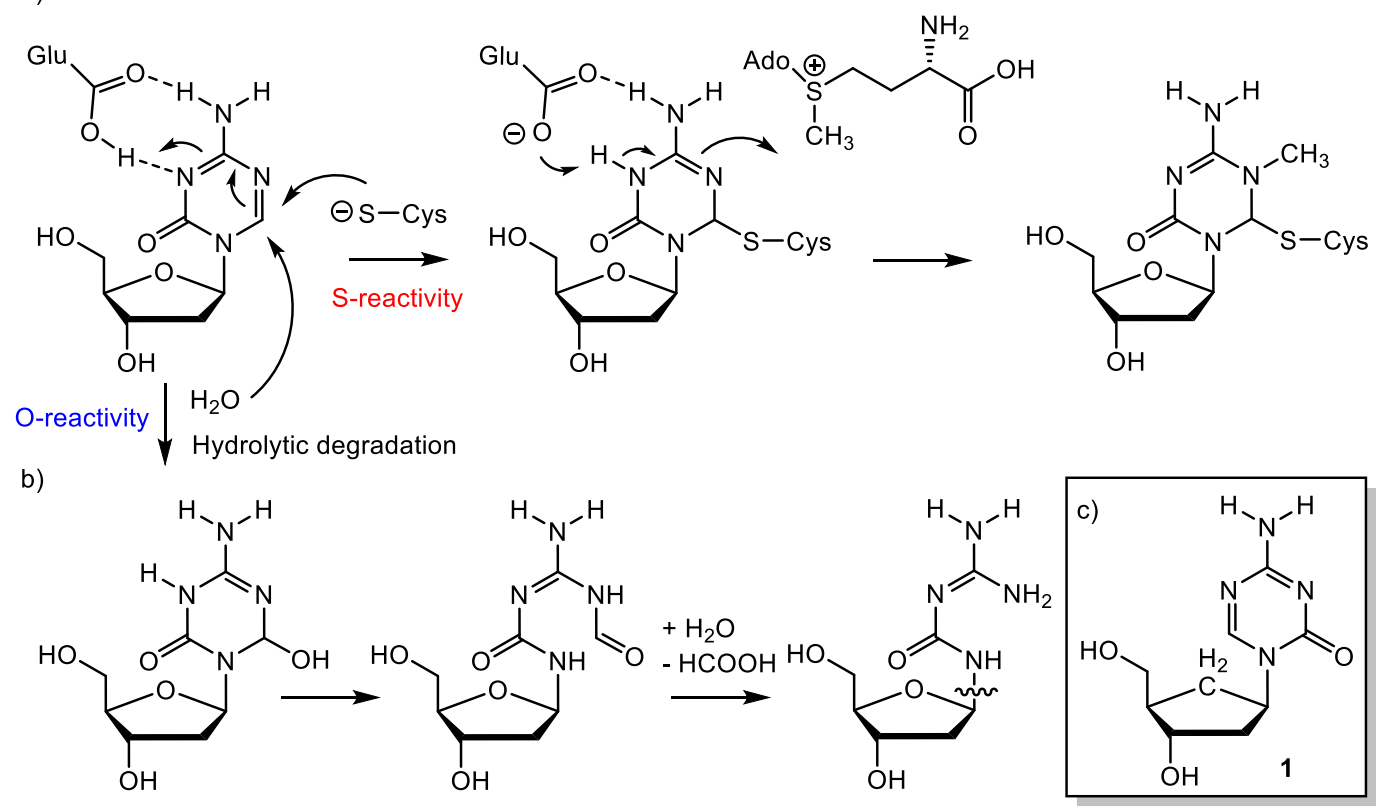

Figure 1. Depiction of 5-aza-2'-deoxycytidine (decitabine, AzadC) together with its mode of action. a) Active site thiol reacts with the C6-position of AzadC. b) Hydrolytic degradation pathway that goes in hand with reaction of a water molecule with the C6-position (O-reactivity) of AzadC. This leads to a final base loss and formation of an abasic site. c) Boxed, depiction of the carbocyclic version cAzadC 1.

The synthesis of cAzadC 1 is depicted in Scheme 1. It starts with the Boc-protected aminocyclopentane derivative 2 that we used previously to synthesize DNA lesion analogues. ${ }^{[12-15]}$ Compound 2 was first benzyl-protected to $\mathbf{3}$, Boc-deprotected to $\mathbf{4}$, and then reacted with carbimidazole $\mathbf{5}$, which was prepared in two steps from isomethylurea 6 after generation of the free base $\mathbf{7}$ with potassium hydroxide and reaction of $\mathbf{7}$ with carbonyldiimidazole. This provides the carbamoylurea-cyclopentane nucleoside analogue 8. Cyclization to the triazine base 9 was subsequently performed with triethylorthoformate. Reaction of 9 with $\mathrm{NH}_{3}$ in methanol and deprotection of the benzyl groups with $\mathrm{BCl}_{3}$ in dichloromethane furnished the final compound CAzadC 1 as the free nucleoside. 


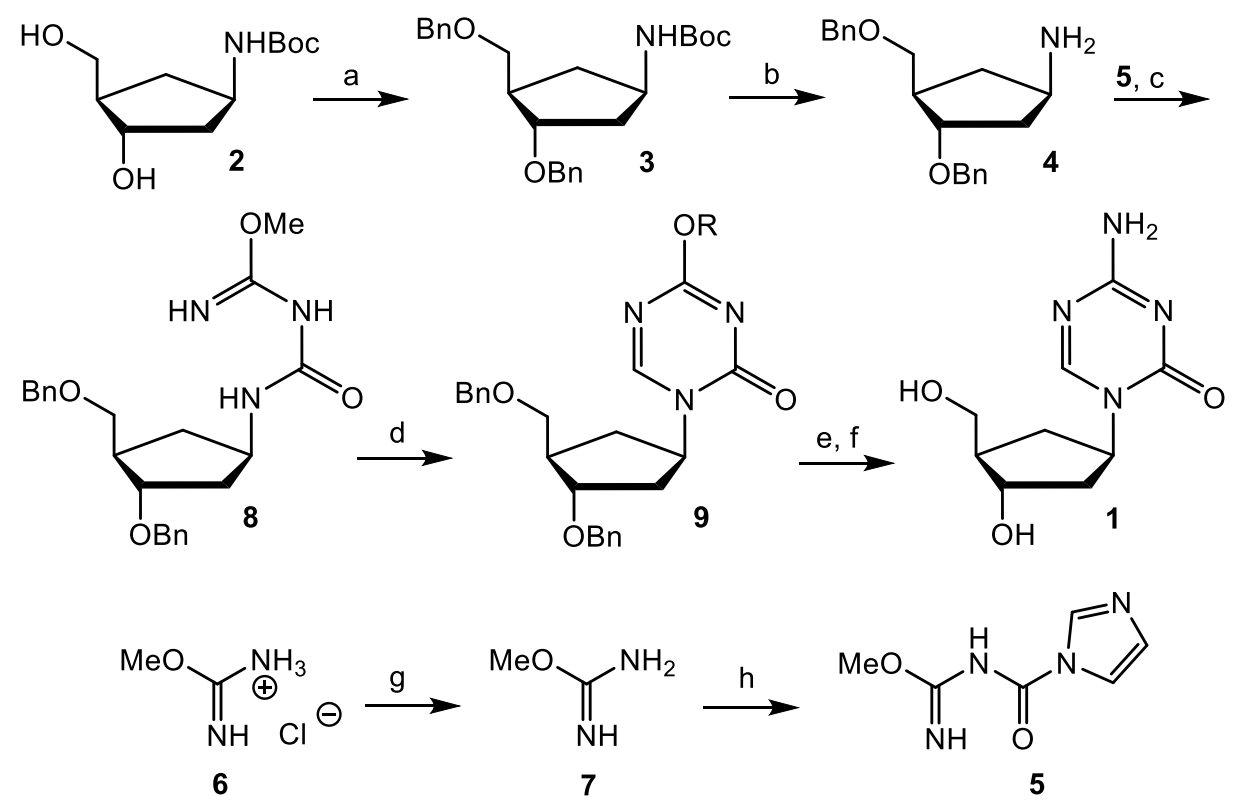

Scheme 1. Synthesis of the carbocyclic 5-aza-2'-deoxycytidine (cAzadC, 1). a) $\mathrm{NaH}, \mathrm{BnBr}, \mathrm{DMF}, 0^{\circ} \mathrm{C}, 1.5 \mathrm{~h}$ and stirred for additional $2 \mathrm{~h}$ at r.t.; b) TFA (30\%), $\mathrm{CH}_{2} \mathrm{Cl}_{2}$ then $\mathrm{Na}_{2} \mathrm{CO}_{3}, 10$ min r.t.; c) $\mathrm{CH}_{3} \mathrm{CN}$, reflux, $2 \mathrm{~h}$ d) $\mathrm{HC}(\mathrm{OEt}) 3$, TFA cat., reflux, 3 h; e) $\mathrm{NH}_{3}(7 \mathrm{~N}, \mathrm{MeOH}), 3 \mathrm{~h}$, r.t., then $\mathrm{H}_{2} \mathrm{O}$;f) $\mathrm{CH}_{2} \mathrm{Cl}_{2},-78{ }^{\circ} \mathrm{C}, \mathrm{BCl}_{3}, 1$ h, then $\rightarrow$ r.t., 2 h, $\mathrm{MeOH}, 20$ min. g) $\mathrm{KOH}, \mathrm{Et}_{2} \mathrm{O}: \mathrm{H}_{2} \mathrm{O}(39: 1)$, $\left.15^{\circ} \mathrm{C}, 30 \mathrm{~min}, \mathrm{~h}\right)$ carbonyldiimidazole, THF, r.t., $3 \mathrm{~h}$; $\mathrm{R}=$ Me or Et.

Recrystallization of compound cAzadC 1 from hot methanol gave colourless needles, which allowed us to solve the crystal structure that is depicted in Fig. 2. Interesting is the observation that cAzadC $\mathbf{1}$ exists with two different cyclopentane conformations in the crystal (Fig. 2; Fig.SI 1). One conformer adopts a C6'-endo $\left(P=88.2^{\circ}, v_{\max }=47.8^{\circ}\right)$ conformation (Fig. 2a), while the second exists as the C2'-endo-C3'exo (South, $\mathrm{P}=150.8^{\circ}, v_{\max }=45.4^{\circ}$ ) conformer (Fig. $2 \mathrm{~b}$ ). The latter conformation is typical for 2'-deoxynucleosides in DNA. This shows that the cAzadC 1 nucleoside can adopt the correct DNA-type conformation, fueling hope that the analogue has the potential to get phosphorylated and integrated into the genome.

a)

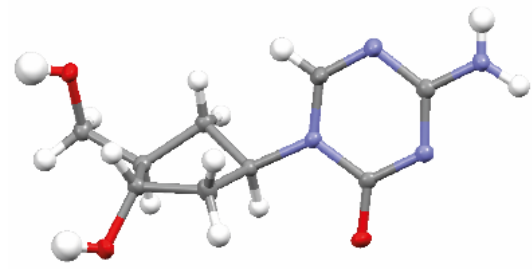<smiles>Nc1ncn(C2C[C@H](O)C[C@@H](O)C2)c(=O)n1</smiles>

C6'-endo

b)

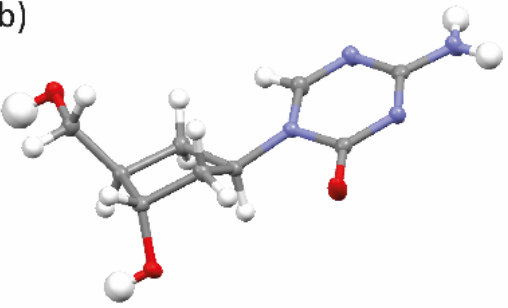<smiles>Nc1ncn(C2CC2CCCO)c(=O)n1</smiles>

Figure 2. Crystal structure of carbocyclic 5-aza-2'-deoxycytidine (cAzadC 1) showing the molecule in the observed C6'-endo conformation (a) and the C2'-endo-C3'-exo conformation $\left({ }^{2} \mathrm{~T}_{1}\right)(\mathrm{b})$. 
We next investigated the stability of cAzadC 1 in direct comparison to the pharmaceutical AzadC (Fig. 3). Since one treatment cycle goes over four weeks we decided to measure the stability at a time point related to a half cycle $(14 \mathrm{~d})$. We dissolved AzadC and cAzadC 1 at a concentration of $100 \mathrm{mM}$ in a phosphate buffer $(100 \mathrm{mM})$ at three different $\mathrm{pH}$ values $(7.4,5.5$ and 8.5$)$ and measured NMR spectra after keeping the solutions at r.t. Since tumour cells often provide an acidic micro-environment, ${ }^{[16]}$ the stability under slightly acidic $\mathrm{pH}$ is particularly informative. As evident from the data shown in Fig. 3, the pharmaceutical AzadC strongly degraded within these $14 \mathrm{~d}$. Importantly, at $\mathrm{pH}=5.5$ and at $\mathrm{pH}=8.5$, intact AzadC was only hardly detectable anymore. At physiological pH (7.4), AzadC was still present after $14 \mathrm{~d}$ but the level of degradation is dramatic. In contrast to these results, we observed for cAzadC 1 surprisingly no degradation at all tested $\mathrm{pH}$ values, including $\mathrm{pH}=5.5$. This result led to the surprising discovery that the simple $\mathrm{O} \rightarrow \mathrm{CH}_{2}$ exchange causes a strong remote disarming effect that seems to change the properties of the triazine ring so that reaction with water is stopped.

$$
\mathrm{pH}=7.4
$$

$\mathrm{pH}=5.5$

$\mathrm{pH}=\mathbf{8 . 5}$

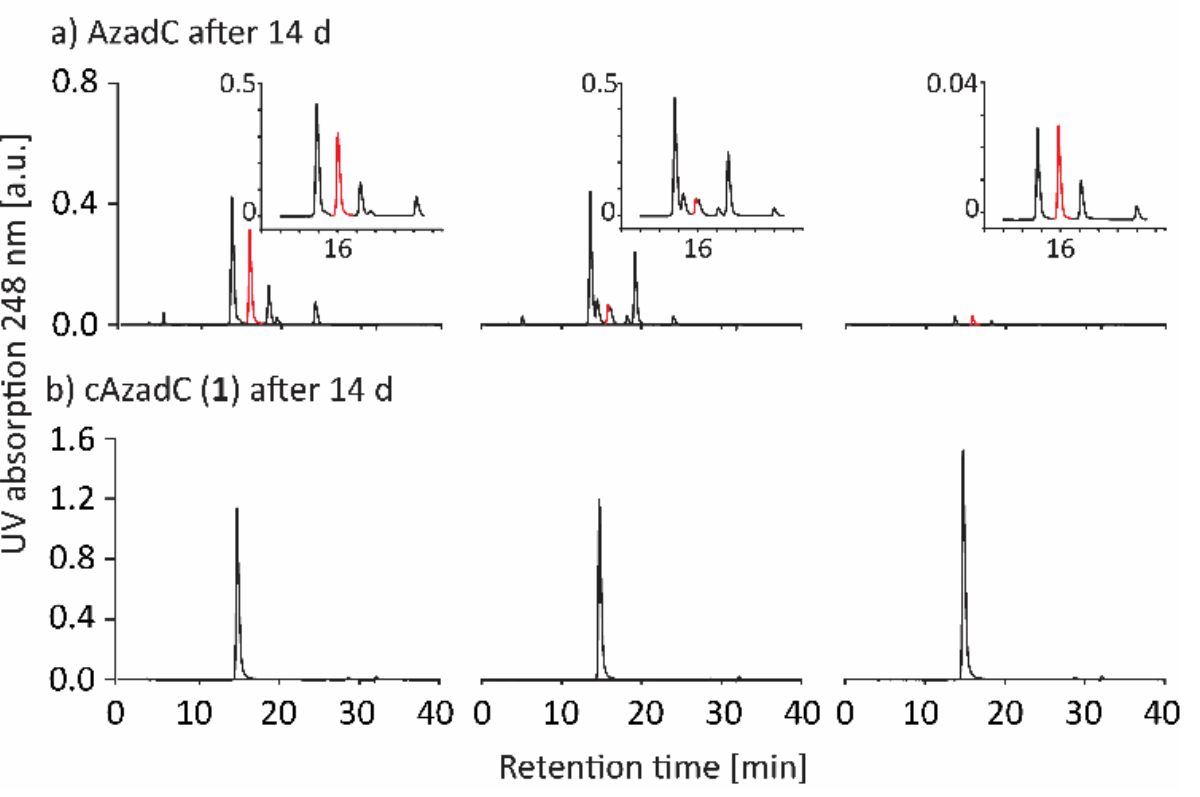

Figure 3. HPLC-based stability measurements showing (a) severe hydrolytic decomposition of 5-aza2'-deoxycytidine (AzadC) solutions at different pH values, while (b) the carbocyclic compound cAzadC 1 was stable at all three $\mathrm{pH}$ values. The inset table in (a) shows the chromatogram between $\mathrm{t} 1=10 \mathrm{~min}$ and $t 2=20$ min for AzadC. The AzadC signal is depicted in red.

We next investigated if this disarming effect would influence the biological functions. We used for this purpose mouse embryonic stem cells (mESC) that were primed in serum/LIF as a model system, since mdC levels increase from naïve to primed state. ${ }^{[17]}$ We added cAzadC 1 in two different concentrations $(1 \mu \mathrm{M}$ and $5 \mu \mathrm{M})$ to $\mathrm{mESC}$ that have been primed for $48 \mathrm{~h}$ and allowed the cells to further proliferate under priming conditions in the presence of cAzadC 1 for additional $72 \mathrm{~h}$. After the $72 \mathrm{~h}$, we harvested the cells, isolated the DNA and digested the DNA down to the nucleoside level using our described protocol. ${ }^{[18]}$ The levels of $\mathrm{mdC}$ were finally precisely quantified using isotope dilution UHPLC-MS ${ }^{2}$. To this end, isotopically labelled standards of the nucleosides were spiked in for exact quantification. ${ }^{[19,18]}$ In addition to mdC, we quantified the levels of 5-hydroxymethyl-2'-deoxycytidine (hmdC), which is formed from $\mathrm{mdC}$ by the action of TET enzymes. ${ }^{[20-21]}$ The absolute levels of $\mathrm{hmdC}$ are in mESC more than ten times lower than the $\mathrm{mdC}$ levels ${ }^{[20,22]}$. The consequence is that even after a substantial reduction of $\mathrm{mdC}$, there should be sufficient $\mathrm{mdC}$ to keep the hmdC levels constant. The question if and by how much the 
hmdC level is affected can therefore inform us about how epigenetic reprogramming is organized. Parallel to the quantification of $\mathrm{mdC}$ and $\mathrm{hmdC}$ we also quantified to which extent cAzadC $\mathbf{1}$ itself was incorporated into the genome of the mESC. Detection of AzadC in the genome of treated cells is only possible after treatment of the DNA with $\mathrm{NaBH}_{4}$. Application of $\mathrm{NaBH}_{4}$ reduces the $\mathrm{C}(5)=\mathrm{C}(6)$ double bond, which stabilizes the compound so that its quantification becomes possible. ${ }^{[23,19]}$ To our delight, we noted that the stability of cAzadC 1 allowed its quantification without this pre-treatment. We also noted that the applied enzymatic digestion protocol allowed to digest genomic DNA (gDNA) even in the presence of large amounts of cAzadC 1 . Taken together, quantification of cAzadC 1 by UHPLC-MS ${ }^{2}$ using an external calibration curve (Fig. SI2) was possible in parallel to quantification of canonical and epigenetic bases.
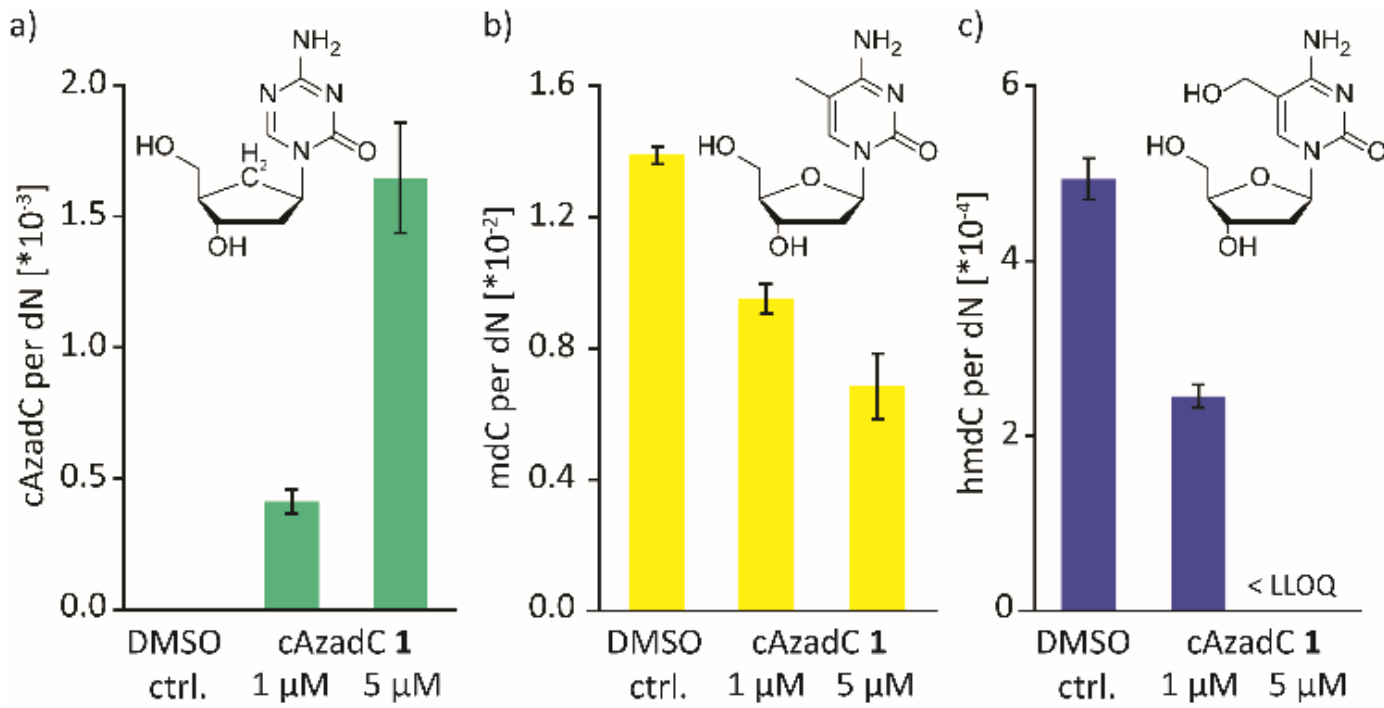

Figure 4. Depiction of the quantification data of DNA modifications of carbocyclic 5-aza-2'-deoxycytidine-treated (cAzadC 1) mouse embryonic stem cells (mESC) obtained by UHPLC-MS ${ }^{2}$. For each condition, three biological replicates were measured in technical triplicates. For each technical replicate, $0.5 \mu \mathrm{g}$ of DNA were digested. Bar graphs represent mean, error bars represent standard deviation. LLOQ indicates the lower limit of quantification.

At $1 \mu \mathrm{M}$ cAzadC 1 concentration, we detected a cAzadC 1 level of $5 \times 10^{-4}$ cAzadC per dN (Fig. 4a). This amounts to almost 3 million cAzadC nucleotides integrated into the genome. At the higher concentration of $5 \mu \mathrm{M}$ cAzadC 1, the level increased 3-fold to $1.7 \times 10^{-3}$ cAzadC per $\mathrm{dN}$ and consequently to more than 8 million integrated cAzadCs per genome. Compared to the incorporation of AzadC, which reaches $1.2 \times 10^{-3}$ AzadC per $\mathrm{dN}$, when applied with $1 \mu \mathrm{M}^{[19]}$, the levels of cAzadC 1 reaches about a third of this level. The data clearly show that the carbocyclic version of AzadC (cAzadC 1) is incorporated and that it reaches in the genome finally comparable levels at $5 \mu \mathrm{M}$ concentration.

Importantly, after exposing the mESC for $72 \mathrm{~h}$ at $1 \mu \mathrm{M}$ cAzadC in the medium, we detected a reduction of the mdC values by almost $30 \%$ (Fig. $4 \mathrm{~b}$ ). At $5 \mu \mathrm{M}$ concentration in the medium, the mdC levels dropped even to about $50 \%$ of the original value. A decrease to $50 \%$ is observed for AzadC as well. Here, however, the $50 \%$-reduction is reached faster $(24 \mathrm{~h})$ and already with lower AzadC concentration $(1 \mu \mathrm{M}){ }^{[19]}$ The data show that the carbocyclic version cAzadC 1 needs simply more time to affect the $\mathrm{mdC}$ levels by the same amount. We believe that this effect is caused by a potentially slower conversion of cAzadC 1 into the triphosphate. The slower kinetics of cAzadC 1, however, is not necessarily a disadvantage given the long treatment times that are applied in the clinic.

Very interesting is also the discovery that the hmdC levels were reduced to about $50 \%$ already in the $1 \mu \mathrm{M}$ experiment. At $5 \mu \mathrm{M}$, we were even unable to detect hmdC above background levels using $0.5 \mu \mathrm{g}$ 
of genomic DNA. The result shows that the hmdC level dropped even faster than the mdC levels, although $\mathrm{hmdC}$ is more than ten times less abundant in the genome. This result is interesting. It indicates that hmdC might be potentially predominantly generated in the $\mathrm{mdC}$ maintenance process during cell division. We see here that compound CAzadC $\mathbf{1}$ is a perfect tool molecule that now allows to gain further insight into the interplay between methylation of $\mathrm{dC}$ to $\mathrm{mdC}$ and oxidation of $\mathrm{mdC}$ to $\mathrm{hmdC}$. With the new compound cAzadC 1 in hand we can now begin to clearly correlate demethylation of the genome with the corresponding cellular effects without compromising DNA damaging effects. Finally, cAzadC 1 may not only be a valuable tool compound but potentially even a next generation epigenetic pharmaceutical. In summary, we show that the replacement of the in-ring $\mathrm{O}$-atom by a $\mathrm{CH}_{2}$-unit stabilizes the pharmaceutical so that its nucleophilic reaction with water is stopped. The new nucleoside cAzadC 1 is accepted by the phosphorylating enzymes in cells and the corresponding cAzadC-triphosphates are efficiently incorporated into the genome. cAzadC 1 is incorporated in the genome with several million nucleotides and it causes the $\mathrm{mdC}$ level to decrease to $70 \%$ relative to the control levels.

\section{Experimental Section}

\section{Synthesis}

All synthetic procedures are described in detail in the supplementary material.

\section{Cell culture of mESC for cAzadC treatment}

Feeder independent wt J1 (strain 129S4/SvJae) ${ }^{[24]}$ cells were cultured in the presence of serum and LIF as previously described ${ }^{[25]}$. They were routinely maintained on gelatinized plates in $2 \mathrm{i} / \mathrm{L}$ medium. For priming experiments, $2 \mathrm{i}$ cultures were passaged when applicable in DMEM supplemented with FBS and LIF as above but lacking the inhibitors. For drug treatment, cells were moved into the primed state by removing $2 \mathrm{i}$ from the medium. Cells were incubated $2 \mathrm{~d}$ in DMEM supplemented with FBS and LIF in 6well plates $(V W R)$. After splitting, $2 \times 10^{5}$ cells were transferred into a 6 -well plate culture dish and supplemented with either $1 \mu \mathrm{M}$ (in $0.01 \%$ DMSO) or $5 \mu \mathrm{M}$ cAzadC (in $0.05 \%$ DMSO) and treated for $72 \mathrm{~h}$. After removal of the medium and washing the cells with DPBS, they were directly lysed with $\mathrm{RLT}^{+}$ buffer as described in a previous publication ${ }^{[18]}$

gDNA isolation, total enzymatic digest and UHPLC-MS ${ }^{2}$

The gDNA was isolated as described previously[18]. Due to the higher stability of cAzadC 1, a hydrogenation procedure was not necessary and the gDNA was directly subjected to a total enzymatic digest and analyzed using UHPLC-MS ${ }^{2}$ as described in a previous publication. ${ }^{[19]}$

\section{Acknowledgements}

We thank the Deutsche Forschungsgemeinschaft (DFG) for financial support via the programs SFB1309 (TP-A4), SFB1361, SPP1784, and GRK2338/1 (P12). This project has received funding from the European Research Council (ERC) under the European Union's Horizon 2020 research and innovation programme (grant agreement $n^{\circ}$ EPiR 741912). F.R.T. thanks the Boehringer Ingelheim Fonds for a PhD fellowship.

Keywords: epigenetics $•$ 5-methyl-2'-deoxycytidine $\cdot$ DNA methylation $\bullet$ antimetabolite $・$ decitabine 


\section{References}

[1] M. Daskalakis, T. T. Nguyen, C. Nguyen, P. Guldberg, G. Kohler, P. Wijermans, P. A. Jones, M. Lubbert, Blood 2002, 100, 2957-2964.

[2] H. Kantarjian, J. P. Issa, C. S. Rosenfeld, J. M. Bennett, M. Albitar, J. DiPersio, V. Klimek, J. Slack, C. de Castro, F. Ravandi, R. Helmer, 3rd, L. Shen, S. D. Nimer, R. Leavitt, A. Raza, H. Saba, Cancer 2006, 106, 1794-1803.

[3] C. Stresemann, F. Lyko, Int. J. Cancer 2008, 123, 8-13.

[4] Y. Koh, Y. A. Kim, K. Kim, J.-A. Sim, S.-S. Yoon, S. M. Park, Y. H. Yun, Blood 2016, 128, $2381-$ 2381.

[5] M. Nieto, P. Demolis, E. Béhanzin, A. Moreau, I. Hudson, B. Flores, H. Stemplewski, T. Salmonson, C. Gisselbrecht, D. Bowen, F. Pignatti, Oncologist 2016, 21, 692-700.

[6] S. S. Smith, B. E. Kaplan, L. C. Sowers, E. M. Newman, Proc. Natl. Acad. Sci. 1992, 89, 47444748.

[7] G. G. Wilson, R. J. Roberts, S. Kumar, J. Posfai, M. Sha, S. Klimasauskas, X. Cheng, Nucleic Acids Res. 1994, 22, 1-10.

[8] A. Bird, Genes Dev. 2002, 16, 6-21.

[9] R. J. Klose, A. P. Bird, Trends Biochem. Sci. 2006, 31, 89-97.

[10] R. Jüttermann, E. Li, R. Jaenisch, Proc. Natl. Acad. Sci. 1994, 91, 11797-11801.

[11] S. Gabbara, A. S. Bhagwat, Biochem. J. 1995, 307, 87-92.

[12] M. Ober, H. Müller, C. Pieck, J. Gierlich, T. Carell, J. Am. Chem. Soc. 2005, 127, 18143-18149.

[13] H. Müller, T. Carell, Eur. J. Org. Chem. 2007, 2007, 1438-1445.

[14] F. Büsch, J. C. Pieck, M. Ober, J. Gierlich, G. W. Hsu, L. S. Beese, T. Carell, Chem. Eur. J. 2008, 14, 2125-2132.

[15] T. H. Gehrke, U. Lischke, K. L. Gasteiger, S. Schneider, S. Arnold, H. C. Müller, D. S. Stephenson, H. Zipse, T. Carell, Nat. Chem. Bio. 2013, 9, 455.

[16] Y. Kato, S. Ozawa, C. Miyamoto, Y. Maehata, A. Suzuki, T. Maeda, Y. Baba, Cancer Cell Int. 2013, 13, 89.

[17] S. Takahashi, S. Kobayashi, I. Hiratani, Cell. Mol. Life Sci. 2018, 75, 1191-1203.

[18] F. R. Traube, S. Schiffers, K. Iwan, S. Kellner, F. Spada, M. Müller, T. Carell, Nat. Protoc. 2019, 14, 283-312.

[19] S. Schiffers, T. M. Wildenhof, K. Iwan, M. Stadlmeier, M. Müller, T. Carell, Helv. Chim. Acta 2019, 102, e1800229.

[20] M. Tahiliani, K. P. Koh, Y. Shen, W. A. Pastor, H. Bandukwala, Y. Brudno, S. Agarwal, L. M. Iyer, D. R. Liu, L. Aravind, A. Rao, Science 2009, 324, 930-935.

[21] S. Ito, L. Shen, Q. Dai, S. C. Wu, L. B. Collins, J. A. Swenberg, C. He, Y. Zhang, Science 2011, 333, 1300-1303.

[22] M. Münzel, D. Globisch, T. Carell, Angew. Chem. Int. Ed. Engl. 2011, 50, 6460-6468.

[23] A. Unnikrishnan, A. N. Q. Vo, R. Pickford, M. J. Raftery, A. C. Nunez, A. Verma, L. B. Hesson, J. E. Pimanda, Leukemia 2018, 32, 900-910.

[24] E. Li, T. H. Bestor, R. Jaenisch, Cell 1992, 69, 915-926.

[25] T. Pfaffeneder, B. Hackner, M. Truss, M. Münzel, M. Müller, C. A. Deiml, C. Hagemeier, T. Carell, Angew. Chem. Int. Ed. Engl. 2011, 50, 7008-7012. 


\section{Supplementary Material}

\section{Synthetic procedures}

tert-Butyl-N-[(1R,3S,4R)-3-hydroxy-4-(hydroxymethyl)cyclopentyl]-carbamate (2)

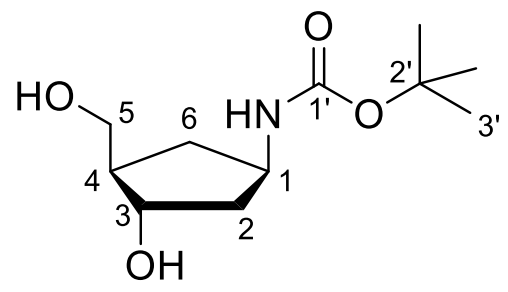

2

$\mathrm{C}_{11} \mathrm{H}_{21} \mathrm{NO}_{4}$

$231.29 \mathrm{~g} / \mathrm{mol}$

2 was synthesized from tert-Butyl- $N-((1 S, 2 R, 4 R, 5 R)-4-(($ tert-butyldimethylsilyloxy)methyl)-6oxa-bicyclo-[3.1.0]-hex-2-yl)-carbamate as described previously. ${ }^{[1]}$

tert-Butyl-N-[(1R,3S,4R)-3-benzyloxy-4-(benzyloxymethyl)-cyclopentyl]-carbamate (3)

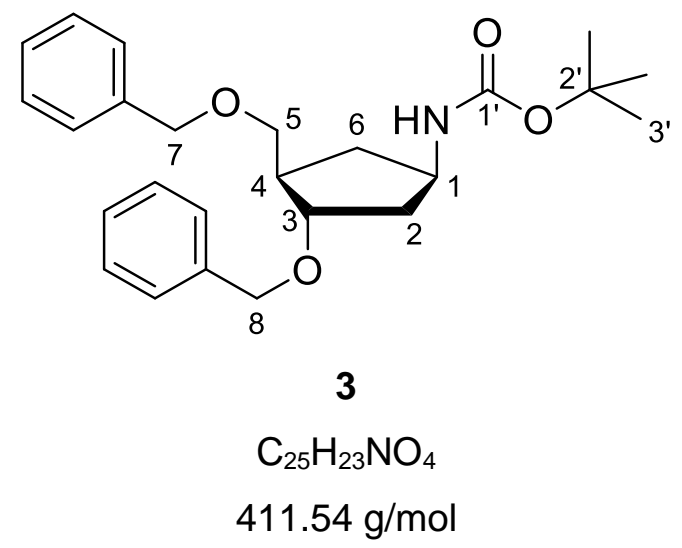

Boc-protected 2 (3.107 g, $13.43 \mathrm{mmol}, 1.0$ eq.) was dissolved in dry DMF (75 mL). The solution was cooled to $0{ }^{\circ} \mathrm{C}$ and $\mathrm{NaH}$ (60\% dispersion in mineral oil, $1.182 \mathrm{~g}, 29.55 \mathrm{mmol}, 2.2 \mathrm{eq}$.) was added in three portions. After $15 \mathrm{~min}$ at $0{ }^{\circ} \mathrm{C}$, benzyl bromide $(4.00 \mathrm{~mL}, 33.58 \mathrm{mmol}, 2.5 \mathrm{eq}$.) was added dropwise. The reaction mixture was stirred for $1.5 \mathrm{~h}$ at $0^{\circ} \mathrm{C}$ and for additional $2 \mathrm{~h}$ at rt. The reaction mixture was diluted using $\mathrm{CH}_{2} \mathrm{Cl}_{2}(30 \mathrm{~mL})$ and the reaction was quenched with sat. $\mathrm{NaHCO}_{3}(30 \mathrm{~mL})$. The mixture was extracted with $\mathrm{CH}_{2} \mathrm{Cl}_{2}(500 \mathrm{~mL})$. The organic phase was washed three times with sat. $\mathrm{NaHCO}_{3}(1 \times 400 \mathrm{~mL}, 2 \times 100 \mathrm{~mL})$ and dried over $\mathrm{Na}_{2} \mathrm{SO}_{4}$. The solvent was removed in vacuo. The crude product was purified by column 
chromatography on silica gel with a stepwise gradient $\mathrm{Hex} / \mathrm{EtOAc}(9: 1 \rightarrow 7: 1 \rightarrow 4: 1)$ to afford product 3 as a colorless solid (3.39 g, $8.24 \mathrm{mmol}, 61 \%)$.

$\mathbf{R}_{\mathbf{f}}=0.67(\mathrm{iHex} / \mathrm{EtOAc}=2: 1)$

$\mathrm{Mp}=74-76^{\circ} \mathrm{C}$

HRMS [ESI+]: [ $\left.{ }_{25} \mathrm{H}_{33} \mathrm{NO}_{4} \mathrm{Na}\right]^{+}$, [M+Na+$]^{+}$calculated.: 434.2292 , found: 434.2299

${ }^{1} \mathrm{H}-\mathrm{NMR}\left(599 \mathrm{MHz}, \mathrm{CDCl}_{3}\right): \delta / \mathrm{ppm}=7.39-7.26(\mathrm{~m}, 10 \mathrm{H}, \mathrm{Ar}-\mathrm{H}), 4.76(\mathrm{~s}, 1 \mathrm{H}, \mathrm{NH}), 4.53-4.37$ $\left(\mathrm{m}, 4 \mathrm{H}, \mathrm{C}_{7}-\mathrm{H}\right.$ and $\left.\mathrm{C}_{8}-\mathrm{H}\right), 4.18-4.08\left(\mathrm{~m}, 1 \mathrm{H}, \mathrm{C}_{1}-\mathrm{H}\right), 3.96-3.87\left(\mathrm{~m}, 1 \mathrm{H}, \mathrm{C}_{3}-\mathrm{H}\right), 3.53-3.41(\mathrm{~m}$, $\left.2 \mathrm{H}, \mathrm{C}_{5}-\mathrm{H}\right), 2.36-2.25\left(\mathrm{~m}, 2 \mathrm{H}, \mathrm{C}_{6}-\mathrm{H}_{\mathrm{a}}, \mathrm{C}_{4}-\mathrm{H}\right), 2.11-2.05\left(\mathrm{~m}, 1 \mathrm{H}, \mathrm{C}_{2}-\mathrm{H}_{\mathrm{a}}\right), 1.77-1.68(\mathrm{~m}, 1 \mathrm{H}$, $\left.\mathrm{C}_{2}-\mathrm{H}_{\mathrm{b}}\right), 1.43\left(\mathrm{~s}, 9 \mathrm{H}, \mathrm{C}_{2^{-}}-\mathrm{H}\right), 1.29-1.20\left(\mathrm{~m}, 1 \mathrm{H}, \mathrm{C}_{6}-\mathrm{H}_{\mathrm{b}}\right)$.

${ }^{13} \mathrm{C}-\mathrm{NMR}\left(151 \mathrm{MHz}, \mathrm{CDCl}_{3}\right): \delta / \mathrm{ppm}=155.5\left(\mathrm{C}_{1}\right), 138.60,138.23,128.36,128.28,127.59$, 127.56, $127.42(\mathrm{C}-\mathrm{Ar}), 81.0\left(\mathrm{C}_{3}\right), 79.2\left(\mathrm{C}_{2^{\prime}}\right), 73.3\left(\mathrm{C}_{8}\right), 71.9\left(\mathrm{C}_{5}\right), 71.3\left(\mathrm{C}_{7}\right), 50.4\left(\mathrm{C}_{1}\right), 44.9\left(\mathrm{C}_{4}\right)$, $39.6\left(\mathrm{C}_{2}\right), 35.0\left(\mathrm{C}_{6}\right), 28.6\left(\mathrm{C}_{2}\right)$.

FTIR (ATR): $\tilde{v} / \mathrm{cm}^{-1}=3339(w), 2973(w), 2929(w), 2858(w), 1692(m), 1496(m), 1453(m)$, $1390(w), 1364(m), 1274(m), 1247(m), 1166(s), 1091(s), 1067(s), 1027(m), 1012(m)$.

(1R, 3S, 4R)-1-Amino-3-benzyloxy-4-(benzyloxymethyl)cyclopentane (4)

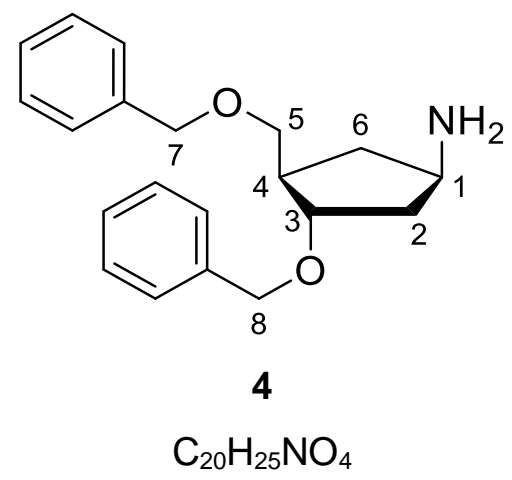

$311,42 \mathrm{~g} / \mathrm{mol}$

A solution of Boc-protected amine $3(3.351 \mathrm{~g}, 8.14 \mathrm{mmol}, 1.0 \mathrm{eq}$.) and trifluoroacetic acid $(12 \mathrm{~mL}, 30 \%(\mathrm{v} / \mathrm{v}))$ in dry $\mathrm{CH}_{2} \mathrm{Cl}_{2}(28 \mathrm{~mL})$ was stirred for $1 \mathrm{~h}$ at rt. After removing the solvent in vacuo, the residue was resuspended in sat. $\mathrm{Na}_{2} \mathrm{CO}_{3}(100 \mathrm{~mL})$ and stirred for $10 \mathrm{~min}$. The mixture was extracted with EtOAc $(3 \times 150 \mathrm{~mL})$ and the combined organic phases were dried over $\mathrm{Na}_{2} \mathrm{SO}_{4}$. Removing the solvent in vacuo resulted in the free amine $\mathbf{4}$ as viscous brown oil, which was used without further purification due to its instability towards $\mathrm{O}_{2}$.

Analytical data of purified 4:

HRMS [ESI $]$ : $\left[\mathrm{C}_{23} \mathrm{H}_{29} \mathrm{~N}_{4} \mathrm{O}_{4} \mathrm{Na}^{+} \text {, [M+Na }\right]^{+}$calculated: 312.1958 , found: 312.1955 
${ }^{1} \mathrm{H}-\mathrm{NMR}\left(400 \mathrm{MHz}, \mathrm{CDCl}_{3}\right): \delta / \mathrm{ppm}=7.38-7.20(\mathrm{~m}, 10 \mathrm{H}, \mathrm{C}-\mathrm{Ar}), 4.57-4.36\left(\mathrm{~m}, 4 \mathrm{H}, \mathrm{C}_{7}, \mathrm{C}_{8}\right)$, $3.95-3.85\left(\mathrm{~m}, 1 \mathrm{H}, \mathrm{C}_{1}\right), 3.62-3.50\left(\mathrm{~m}, 1 \mathrm{H}, \mathrm{C}_{3}\right), 3.50-3.39\left(\mathrm{~m}, 2 \mathrm{H}, \mathrm{C}_{5}\right), 2.41-2.28(\mathrm{~m}, 1 \mathrm{H}$, $\left.\mathrm{C}_{4}\right), 2.28-2.13\left(\mathrm{~m}, 1 \mathrm{H}, \mathrm{C}_{6}-\mathrm{H}_{\mathrm{a}}\right), 2.13-1.96\left(\mathrm{~m}, 3 \mathrm{H}, \mathrm{NH}_{2}, \mathrm{C}_{2}-\mathrm{H}_{\mathrm{a}}\right), 1.65-1.50\left(\mathrm{~m}, 1 \mathrm{H}, \mathrm{C}_{2}-\mathrm{H}_{\mathrm{b}}\right)$, $1.19-1, .08\left(\mathrm{~m}, 1 \mathrm{H}, \mathrm{C}_{6}-\mathrm{H}_{\mathrm{a}}\right)$,

${ }^{13} \mathrm{C}-\mathrm{NMR}\left(101 \mathrm{MHz}, \mathrm{CDCl}_{3}\right): \delta / \mathrm{ppm}=138.8,138.4,128.5,128.5,127.79,127.75,127.7,127.6$ $(\mathrm{C}-\mathrm{Ar}), 81.82\left(\mathrm{C}_{3}\right), 73.23\left(\mathrm{C}_{7}\right), 72.58\left(\mathrm{C}_{5}\right), 71.10\left(\mathrm{C}_{8}\right), 51.40\left(\mathrm{C}_{1}\right), 45.63\left(\mathrm{C}_{4}\right), 42.07\left(\mathrm{C}_{2}\right), 38.08$ $\left(\mathrm{C}_{6}\right)$.

2-Methyl-1-(1-imidazoylcarbonyl)-isourea (5)<smiles>[2H]OC(=N)NC(=O)n1ccnc1</smiles>

5

$\mathrm{C}_{6} \mathrm{H}_{8} \mathrm{~N}_{4} \mathrm{O}_{4}$

$168.16 \mathrm{~g} / \mathrm{mol}$

To a solution of $\mathrm{O}$-methylisourea hydrochloride $6\left(5.00 \mathrm{~g}, 45.65 \mathrm{mmol}, 1.0\right.$ eq.) in $\mathrm{Et}_{2} \mathrm{O}: \mathrm{H}_{2} \mathrm{O}$ (39:1) at $-15^{\circ} \mathrm{C}, \mathrm{KOH}$ powder (51.22 g, $912.96 \mathrm{mmol}, 20.0$ eq.) was added portion wise under constant stirring. After $30 \mathrm{~min}$, the mixture was filtrated, and the residue was washed with icecold $\mathrm{Et}_{2} \mathrm{O}(3 \times 50 \mathrm{~mL})$. The combined organic phases were concentrated to $20 \mathrm{~mL}$ in vacuo. Cooling to $-20^{\circ} \mathrm{C}$ resulted in precipitation. Vacuum filtration under $\mathrm{N}_{2}$ flow resulted in O-methylisourea 7 as a colorless wax $(1.759 \mathrm{~g}, 23.74 \mathrm{mmol}, 52 \%)$. A solution of $7(1.24 \mathrm{~g}$, $16.74 \mathrm{mmol}, 1.0$ eq.) and carbonyldiimidazole $(2.90 \mathrm{~g}, 17.91 \mathrm{mmol}, 1.07$ eq. $)$ in dry THF (35 mL) was stirred for $3 \mathrm{~h}$ at rt. After $1 \mathrm{~h}$, a colorless precipitate was observed. The reaction mixture was concentrated to $3 \mathrm{~mL}$ in vacuo and filtrated. The residue was washed with ice-cold THF $(2 \times 3 \mathrm{~mL})$ and the combined organic phases were lyophilized, which resulted in colorless solid 5 (1.946 g, $11.57 \mathrm{mmol}, 69 \%)$.

${ }^{1} \mathrm{H}-\mathrm{NMR}\left(400 \mathrm{MHz}, \mathrm{CDCl}_{3}\right): \delta / \mathrm{ppm}=8.60(\mathrm{br} \mathrm{s}, 1 \mathrm{H}, \mathrm{N}-\mathrm{H}), 8.35(\mathrm{~s}, 1 \mathrm{H}, \mathrm{Ar}-\mathrm{H}), 7.58(\mathrm{~s}, 1 \mathrm{H}, \mathrm{Ar}-$ $\mathrm{H}), 7.04$ (s, 1H, Ar-H), 6.04 (br s, 1H, N-H), 3.96 (s, 3H, $\left.\mathrm{C}_{2}-\mathrm{H}\right)$.

${ }^{13} \mathrm{C}-\mathrm{NMR}\left(101 \mathrm{MHz}, \mathrm{CDCl}_{3}\right): \delta / \mathrm{ppm}=165.7\left(\mathrm{C}_{1}\right), 157.3(\mathrm{C} 3), 137.5(\mathrm{Ar}), 130.0(\mathrm{Ar}), 117.2(\mathrm{Ar})$, $55.3\left(\mathrm{C}_{2}\right)$. 


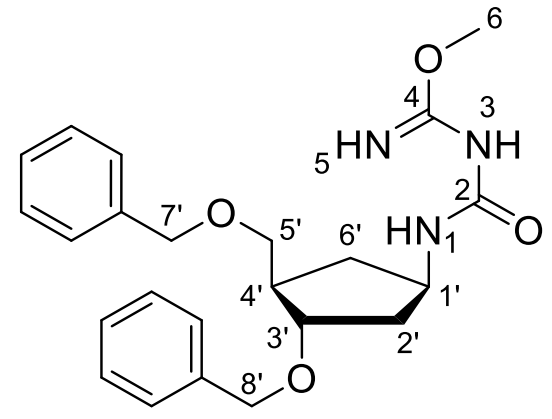

8

$\mathrm{C}_{23} \mathrm{H}_{29} \mathrm{~N}_{4} \mathrm{O}_{4}$

$411.50 \mathrm{~g} / \mathrm{mol}$

The crude product 4 was dissolved in dry acetonitrile $(75 \mathrm{~mL})$ and the carbonyl imidazole 5 (1.506 g, $8.96 \mathrm{mmol}, 1.1 \mathrm{eq}$.) was added. The mixture was refluxed for $2 \mathrm{~h}$. The solvent was removed in vacuo. The crude product was purified by column chromatography on silica gel with a stepwise gradient of $i \mathrm{Hex} / \mathrm{EtoAc}(2: 1 \rightarrow 1: 1)$ to obtain the methylisobiurete 8 as a yellow oil $(2.613 \mathrm{~g}, 6.35 \mathrm{mmol}, 78 \%)$.

$\mathbf{R}_{\mathbf{f}}=0.51(\mathrm{DCM} / \mathrm{MeOH}=19: 1)$

HRMS [ESI ${ }^{+}$: $\left[\mathrm{C}_{23} \mathrm{H}_{29} \mathrm{~N}_{4} \mathrm{O}_{4} \mathrm{Na}\right]^{+}$, [M+Na+$]^{+}$calculated: 434.2050 , found: 434.2049

${ }^{1} \mathrm{H}-\mathrm{NMR}\left(599 \mathrm{MHz}, \mathrm{CDCl}_{3}\right): \delta / \mathrm{ppm}=7.35-7.16(\mathrm{~m}, 10 \mathrm{H}, \mathrm{Ar}-\mathrm{H}), 5.42\left(\mathrm{~d},{ }^{3} \mathrm{~J}^{1}, \mathrm{~N} 1=7.8 \mathrm{~Hz}, 1 \mathrm{H}\right.$, $\left.\mathrm{N}_{1}-\mathrm{H}\right), 4.50-4.34\left(\mathrm{~m}, 4 \mathrm{H}, \mathrm{C}_{7^{-}}-\mathrm{H}_{\mathrm{a}, \mathrm{b}}, \mathrm{C}_{8^{\prime}}-\mathrm{H}_{\mathrm{a}, \mathrm{b}}\right), 4.33-4.16\left(\mathrm{~m}, 1 \mathrm{H}, \mathrm{C}_{1^{\prime}}-\mathrm{H}\right), 3.93-3.81(\mathrm{~m}, 1 \mathrm{H}$,

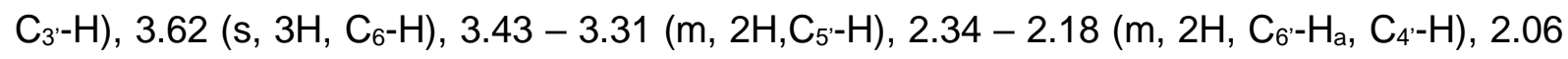
(ddd, ${ }^{2} \mathrm{~J}_{2^{\prime} \mathrm{a}, 2^{\prime} \mathrm{b}}=13,0 \mathrm{~Hz},{ }^{3} \mathrm{~J}_{2^{\prime} \mathrm{a}, 1^{\prime} / 3^{\prime}}=6,9 \mathrm{~Hz},{ }^{3} \mathrm{~J}_{2^{\prime} \mathrm{a}, 1^{\prime} / 3^{\prime}}=4,6 \mathrm{~Hz}, 1 \mathrm{H}, \mathrm{C}_{2^{\prime}}-\mathrm{H}_{\mathrm{a}}$ ), 1.73 (ddd, $\left.{ }^{2} J_{2^{\prime} \mathrm{a}, 2 \mathrm{~b}^{\prime}}=13.0 \mathrm{~Hz},{ }^{3} J_{2^{\prime} \mathrm{b}, 1^{\prime} / 3^{\prime}}=7.0 \mathrm{~Hz},{ }^{3} J_{2^{\prime} \mathrm{b}, 1^{\prime} / 4^{\prime}}=7.0 \mathrm{~Hz}, 1 \mathrm{H}, \mathrm{C}_{2^{\prime}}-\mathrm{H}_{\mathrm{b}}\right), 1.28-1.11\left(\mathrm{~m}, 1 \mathrm{H}, \mathrm{C}_{6^{\prime}}-\mathrm{H}_{\mathrm{b}}\right)$.

${ }^{13} \mathrm{C}-N M R\left(151 \mathrm{MHz}, \mathrm{CDCl}_{3}\right): \delta / \mathrm{ppm}=163.8\left(\mathrm{C}_{2}\right), 162.3\left(\mathrm{C}_{4}\right), 138.9\left(\mathrm{C}_{\mathrm{Ar}}\right), 138.5\left(\mathrm{C}_{\mathrm{Ar}}\right), 128.51$ $\left(\mathrm{C}_{\mathrm{Ar}}\right), 128.41\left(\mathrm{C}_{\mathrm{Ar}}\right), 127.76\left(\mathrm{C}_{\mathrm{Ar}}\right), 127.74\left(\mathrm{C}_{\mathrm{Ar}}\right), 127.70\left(\mathrm{C}_{\mathrm{Ar}}\right), 127.56\left(\mathrm{C}_{\mathrm{Ar}}\right), 81.1\left(\mathrm{C}_{3^{\prime}}\right), 73.3$ $\left(\mathrm{C}_{7^{\prime}}\right), 71.9\left(\mathrm{C}_{5^{\prime}}\right), 71.2\left(\mathrm{C}_{8^{\prime}}\right), 53.8\left(\mathrm{C}_{6}\right), 49.5\left(\mathrm{C}_{1^{\prime}}\right), 45.0\left(\mathrm{C}_{4^{\prime}}\right), 39.5\left(\mathrm{C}_{2^{\prime}}\right), 35.0\left(\mathrm{C}_{6^{\prime}}\right)$. 


\section{4-Ethoxy-1-[(1'R,3' S,4' R)-3'-benzyloxy-4'-(benzyloxymethyl)-cyclopentyl]-1H-[1,3,5]-}

triazin-2-one (9a) and 4-methoxy-1-[(1'R,3' $\left.S, 4^{\prime} R\right)$-3'-benzyloxy-4'-(benzyloxymethyl)cyclopentyl]-1H-[1,3,5]-triazin-2-one (9b)

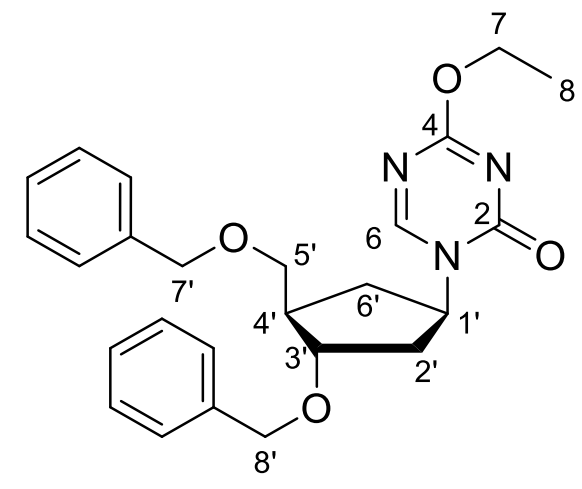

$9 \mathbf{a}$

$\mathrm{C}_{25} \mathrm{H}_{29} \mathrm{~N}_{3} \mathrm{O}_{4}$

$435.52 \mathrm{~g} / \mathrm{mol}$

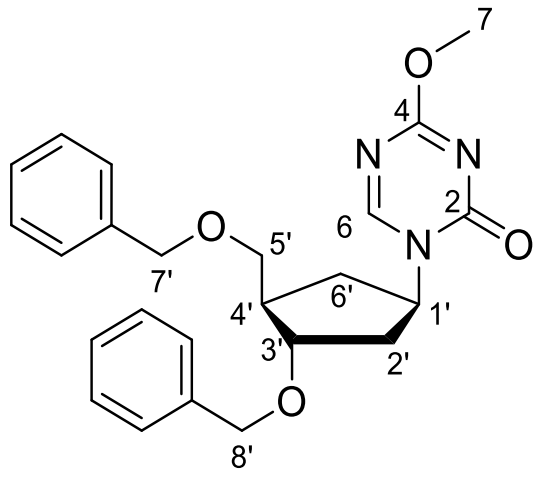

96

$\mathrm{C}_{24} \mathrm{H}_{27} \mathrm{~N}_{3} \mathrm{O}_{4}$

$421.50 \mathrm{~g} / \mathrm{mol}$

Trifluoroacetic acid $(75 \mu \mathrm{L})$ was added to a solution of $8(2.613 \mathrm{~g}, 6.35 \mathrm{mmol}, 1.0 \mathrm{eq})$ in triethyl ortho-formiate $(60 \mathrm{~mL})$. The mixture was refluxed for $3 \mathrm{~h}$. The solvent was removed in vacuo. The residue was co-evaporated once with $\mathrm{MeOH}$ and the crude product was purified by column chromatography on silica gel with a stepwise gradient of $\mathrm{Hex} / \mathrm{EtOAc}(2: 1 \rightarrow 1: 1 \rightarrow 1: 2)$ to obtain 9a (1.774 g, $4.07 \mathrm{mmol}, 64 \%$, colorless solid) and 9b (268.0 mg, 0,64 mmol, 10\%, colorless oil).

9a:

$\mathbf{R}_{\mathbf{f}}=0.71($ iHex/EtOAc, 1:3)

HRMS [ESI+]: $\left[\mathrm{C}_{25} \mathrm{H}_{30} \mathrm{~N}_{3} \mathrm{O}_{4} \mathrm{H}\right]^{+},\left[\mathrm{M}_{+} \mathrm{H}^{+}\right]^{+}$calculated: 436.2232 , found.: 436.2231.

${ }^{1} \mathrm{H}-\mathrm{NMR}\left(400 \mathrm{MHz}, \mathrm{CDCl}_{3}\right): \delta / \mathrm{ppm}=8.23\left(\mathrm{~s}, 1 \mathrm{H}, \mathrm{C}_{6}-\mathrm{H}\right), 7.38-7.24(\mathrm{~m}, 10 \mathrm{H}, \mathrm{Ar}-\mathrm{H}), 5.07-$

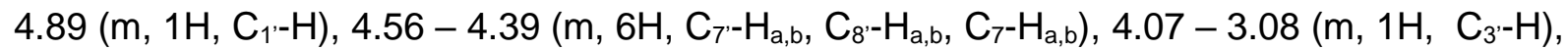
$3.61-3.46\left(\mathrm{~m}, 2 \mathrm{H}, \mathrm{C}_{5^{\prime}}-\mathrm{H}_{\mathrm{a}, \mathrm{b}}\right), 2.52-2.36\left(\mathrm{~m}, 2 \mathrm{H}, \mathrm{C}_{6^{\prime}}-\mathrm{H}_{\mathrm{a}}, \mathrm{C}_{4^{\prime}}-\mathrm{H}\right), 2.28\left(\mathrm{ddd}, 1 \mathrm{H},{ }^{2} \mathrm{~J}_{2^{\prime} \mathrm{a}, 2^{\prime} \mathrm{b}}=13,3\right.$

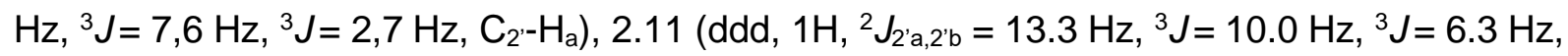

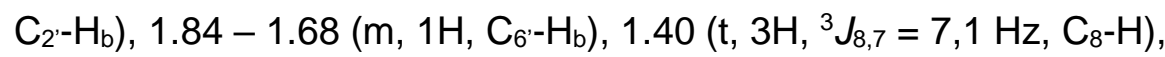

${ }^{13} \mathrm{C}-\mathrm{NMR}\left(101 \mathrm{MHz}, \mathrm{CDCl}_{3}\right): \delta / \mathrm{ppm}=169.3\left(\mathrm{C}_{4}\right), 158.4\left(\mathrm{C}_{6}\right), 155.0\left(\mathrm{C}_{2}\right), 138.2\left(\mathrm{C}_{\mathrm{Ar}}\right), 138.1$ $\left(\mathrm{C}_{\mathrm{Ar}}\right), 128.6\left(\mathrm{C}_{\mathrm{Ar}}\right), 128.6\left(\mathrm{C}_{\mathrm{Ar}}\right), 127.93\left(\mathrm{C}_{\mathrm{Ar}}\right), 127.85\left(\mathrm{C}_{\mathrm{Ar}}\right), 127.82\left(\mathrm{C}_{\mathrm{Ar}}\right), 80.4\left(\mathrm{C}_{3^{\prime}}\right), 73.4\left(\mathrm{C}_{7^{\prime} / 8^{\prime}}\right)$, $71.26\left(\mathrm{C}_{7^{\prime} / 8^{\prime}}\right), 71.25\left(\mathrm{C}_{5^{\prime}}\right), 65.1\left(\mathrm{C}_{7}\right), 56.8\left(\mathrm{C}_{1^{\prime}}\right), 44.9\left(\mathrm{C}_{4^{\prime}}\right), 36.9\left(\mathrm{C}_{2^{\prime}}\right), 32.6\left(\mathrm{C}_{6^{\prime}}\right), 14.2\left(\mathrm{C}_{8}\right)$. 
9b:

$\mathbf{R}_{\mathbf{f}}=0.63($ iHex/EtOAc, 1:3)

HRMS [ESI $\left.{ }^{+}\right]:\left[\mathrm{C}_{24} \mathrm{H}_{28} \mathrm{~N}_{3} \mathrm{O}_{4}\right]^{+},\left[\mathrm{M}+\mathrm{H}^{+}\right]^{+}$calculated: 422.2074 , found: 422.2075.

${ }^{1} \mathrm{H}-\mathrm{NMR}\left(599 \mathrm{MHz}, \mathrm{CDCl}_{3}\right): \delta / \mathrm{ppm}==8.23\left(\mathrm{~s}, 1 \mathrm{H}, \mathrm{C}_{6}-\mathrm{H}\right), 7.38-7.25(\mathrm{~m}, 10 \mathrm{H}, \operatorname{Ar}-\mathrm{H})$, $5.04-4.93\left(\mathrm{~m}, 1 \mathrm{H}, \mathrm{C}_{1^{\prime}}{ }^{-\mathrm{H}}\right), 4.57-4.43\left(\mathrm{~m}, 6 \mathrm{H}, \mathrm{C}_{7^{\prime}}-\mathrm{H}_{\mathrm{a}, \mathrm{b}}, \mathrm{C}_{8^{\prime}} \mathrm{H}_{\mathrm{a}, \mathrm{b}}\right), 4.09-3.98\left(\mathrm{~m}, 4 \mathrm{H}, \mathrm{C}_{3^{\prime}}-\mathrm{H}\right.$,

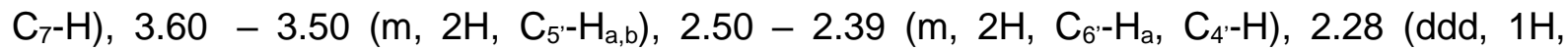
${ }^{2} J_{2^{\prime}, 2^{\prime} \mathrm{b}}=13,1 \mathrm{~Hz},{ }^{3} J=7,4 \mathrm{~Hz},{ }^{3} \mathrm{~J}=2,7 \mathrm{~Hz}, \mathrm{C}_{2^{\prime}}-\mathrm{H}_{\mathrm{a}}$ ), 2.11 (ddd, $1 \mathrm{H},{ }^{2} \mathrm{~J}_{2^{\prime} \mathrm{a}, 2^{\prime} \mathrm{b}}=13.1 \mathrm{~Hz},{ }^{3} \mathrm{~J}=10.1$ $\left.\mathrm{Hz},{ }^{3} \mathrm{~J}=6.3 \mathrm{~Hz}, \mathrm{C}_{2}-\mathrm{H}_{\mathrm{b}}\right), 1.80-1.68\left(\mathrm{~m}, 1 \mathrm{H}, \mathrm{C}_{6^{\prime}}-\mathrm{H}_{\mathrm{b}}\right)$.

${ }^{13} \mathrm{C}-N M R\left(101 \mathrm{MHz}, \mathrm{CDCl}_{3}\right): \delta / \mathrm{ppm}=169.9\left(\mathrm{C}_{4}\right), 158.5\left(\mathrm{C}_{6}\right), 155.0\left(\mathrm{C}_{2}\right), 138.3\left(\mathrm{C}_{\mathrm{Ar}}\right)$, 138,0 $\left(\mathrm{C}_{\mathrm{Ar}}\right), 128.63\left(\mathrm{C}_{\mathrm{Ar}}\right), 128.57\left(\mathrm{C}_{\mathrm{Ar}}\right), 127.93\left(\mathrm{C}_{\mathrm{Ar}}\right), 127.84\left(\mathrm{C}_{\mathrm{Ar}}\right), 127.82\left(\mathrm{C}_{\mathrm{Ar}}\right), 80.4\left(\mathrm{C}_{3^{\prime}}\right)$, $73.5\left(\mathrm{C}_{7^{\prime} / 8^{\prime}}\right), 71.3\left(\mathrm{C}_{7^{\prime} / 8^{\prime}}\right), 56.9\left(\mathrm{C}_{1^{\prime}}\right), 56.0\left(\mathrm{C}_{7}\right), 44.9\left(\mathrm{C}_{4^{\prime}}\right), 36.9\left(\mathrm{C}_{2^{\prime}}\right), 32.6\left(\mathrm{C}_{6^{\prime}}\right)$.

\section{4-Amino-1-[(1'R,3' S,4' R)-3'-benzyloxy-4'-(benzyloxymethyl)-cyclopentyl]-1H-}

\section{$[1,3,5]$ triazin-2-one $(10)$}

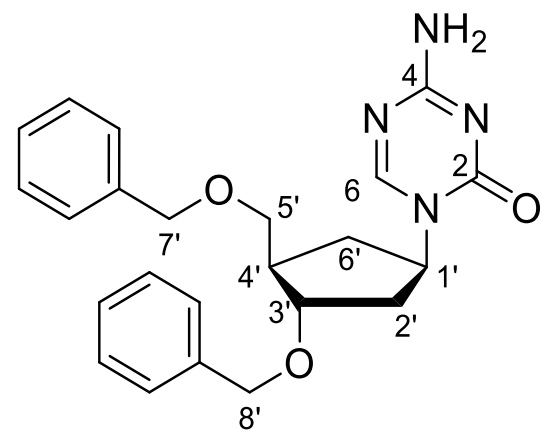

10

$\mathrm{C}_{23} \mathrm{H}_{26} \mathrm{~N}_{4} \mathrm{O}_{3}$

$406.47 \mathrm{~g} / \mathrm{mol}$

Ethoxytriazine $9 \mathrm{a}\left(1.630 \mathrm{~g}, 3.74 \mathrm{mmol}, 1.0\right.$ eq.) was dissolved in methanolic $\mathrm{NH}_{3}(7 \mathrm{~N} \mathrm{in} \mathrm{MeOH}$, $60 \mathrm{~mL})$ and stirred for $3 \mathrm{~h}$ at rt. The mixture was diluted with $\mathrm{H}_{2} \mathrm{O}(340 \mathrm{~mL})$, resulting in a colorless precipitate, which was extracted wit EtOAc $(3 \times 200 \mathrm{~mL})$. The organic phases were combined, dried and the solvent was removed in vacuo, which is resulted in the benzylprotected cAzadC 10 (1.478 g, $3.63 \mathrm{mmol}, 97 \%)$ as a colorless foam. Synthesis of 10 was also successful starting from the methoxytriazine $9 \mathrm{~b}$ and following the same procedure.

$\mathbf{R}_{\mathbf{f}}=0.50\left(\mathrm{CH}_{2} \mathrm{Cl}_{2} / \mathrm{MeOH}, 9: 1\right)$

HRMS [ESI ]: $\left[\mathrm{C}_{23} \mathrm{H}_{27} \mathrm{~N}_{4} \mathrm{O}_{3}\right]^{+},\left[\mathrm{M}+\mathrm{H}^{+}\right]^{+}$calculated: 407.2078, found.: 407.2081 . 
${ }^{1} \mathrm{H}-\mathrm{NMR}\left(599 \mathrm{MHz}, \mathrm{CDCl}_{3}\right): \delta / \mathrm{ppm}=8.01\left(\mathrm{~s}, 1 \mathrm{H}, \mathrm{C}_{6}-\mathrm{H}\right), 7.35-7.23(\mathrm{~m}, 10 \mathrm{H}, \mathrm{Ar}-\mathrm{H}), 5.78(\mathrm{~s}$,

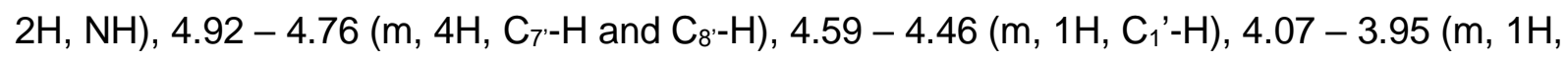
$\mathrm{C}_{3^{\prime}-\mathrm{H}}$ ), $3.55-3.45\left(\mathrm{~m}, 2 \mathrm{H}, \mathrm{C}_{5^{\prime}}-\mathrm{H}\right), 2.44-2.28\left(\mathrm{~m}, 2 \mathrm{H}, \mathrm{C}_{6^{\prime}}-\mathrm{H}_{\mathrm{a}}, \mathrm{C}_{4^{\prime}}-\mathrm{H}\right), 2.24-2.16\left(\mathrm{~m}, 1 \mathrm{H}, \mathrm{C}_{2^{\prime}}\right.$ $\left.\mathrm{H}_{\mathrm{a}}\right), 2.14-2.05\left(\mathrm{~m}, 1 \mathrm{H}, \mathrm{C}_{2}-\mathrm{H}_{\mathrm{b}}\right), 1.78-1.67\left(\mathrm{~m}, 1 \mathrm{H}, \mathrm{C}_{6^{\prime}} \mathrm{H}_{\mathrm{b}}\right)$.

${ }^{13} \mathrm{C}-\mathrm{NMR}\left(151 \mathrm{MHz}, \mathrm{CDCl}_{3}\right): \delta / \mathrm{ppm}=165.7\left(\mathrm{C}_{4}\right), 157.1\left(\mathrm{C}_{6}\right), 154.2\left(\mathrm{C}_{2}\right), 138.3,138.3,128.6$, 128.5, 127.84, $127.78(\mathrm{C}-\mathrm{Ar}), 80.4\left(\mathrm{C}_{3^{\prime}}\right), 73.4\left(\mathrm{C}_{8^{\prime}}\right), 71.4\left(\mathrm{C}_{5^{\prime}}\right), 71.2\left(\mathrm{C}_{8^{\prime}}\right), 56.7\left(\mathrm{C}_{1^{\prime}}\right), 44.9\left(\mathrm{C}_{4^{\prime}}\right)$, $36.8\left(\mathrm{C}_{2^{\prime}}\right), 32.5\left(\mathrm{C}_{6^{\prime}}\right)$.

4-Amino-1-[(1'R,3'S,4'R)-3'-hydroxy-4'-(hydroxymethyl)-cyclopentyl]-1H-[1,3,5]triazin-2on (cAzadC, 1)

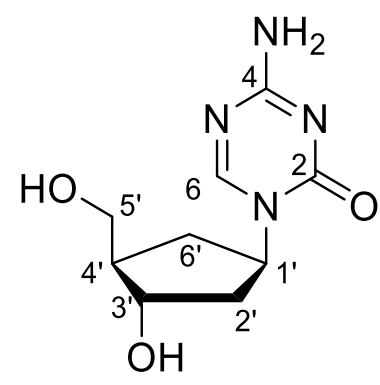

1

$\mathrm{C}_{9} \mathrm{H}_{14} \mathrm{~N}_{4} \mathrm{O}_{3}$

$226.24 \mathrm{~g} / \mathrm{mol}$

A solution of benzyl-protected 10 (1.478 g, $3.63 \mathrm{mmol}, 1.0 \mathrm{eq})$ in $\mathrm{CH}_{2} \mathrm{Cl}_{2}(100 \mathrm{~mL})$ was cooled to $-78^{\circ} \mathrm{C}$ and $\mathrm{BCl}_{3}(1 \mathrm{M}$ in $\mathrm{DCM}, 12.7 \mathrm{~mL}, 12.7 \mathrm{mmol}, 3.5$ eq.) was added dropwise. The mixture was stirred for $1 \mathrm{~h}$ at $-78^{\circ} \mathrm{C}$ and stirred for additional $2 \mathrm{~h}$ at rt. The reaction was quenched by addition of $\mathrm{MeOH}(85 \mathrm{~mL})$ under constant stirring. The solvent was removed in vacuo. The crude product was purified by column chromatography on silica gel with a stepwise gradient $\mathrm{CH}_{2} \mathrm{Cl}_{2} / \mathrm{MeOH}(9: 1 \rightarrow 7: 3)$ to obtain cAzadC (1, 0.740g, $\left.3.27 \mathrm{mmol}, 90 \%\right)$. Recrystallization from hot $\mathrm{MeOH}$ resulted in 57\% cAzadC (1, $465.3 \mathrm{mg}, 2.06 \mathrm{mmol}$ ) as colorless acicular monocrystalls.

$\mathbf{R}_{\mathbf{f}}=0.1\left(\mathrm{CH}_{2} \mathrm{Cl}_{2} / \mathrm{MeOH}, 9: 1\right)$

Mp.: $198-200^{\circ} \mathrm{C}$

HRMS [ESI ${ }^{+}$: $\left[\mathrm{C}_{9} \mathrm{H}_{15} \mathrm{~N}_{4} \mathrm{O}_{3}\right]^{+},\left[\mathrm{M}+\mathrm{H}^{+}\right]^{+}$calculated: 227,1138 , found.: 227,1139 .

${ }^{1} \mathrm{H}-\mathrm{NMR}\left(400 \mathrm{MHz}, \mathrm{D}_{2} \mathrm{O}\right): \delta / \mathrm{ppm}=8.29\left(\mathrm{~s}, 1 \mathrm{H}, \mathrm{C}_{6}-\mathrm{H}\right), 4.90-4.62\left(\mathrm{~m}, 1 \mathrm{H}, \mathrm{C}_{1^{\prime}}-\mathrm{H}\right.$, Overlap with $\mathrm{D}_{2} \mathrm{O}$ signal), $4.29-4.16\left(\mathrm{~m}, 1 \mathrm{H}, \mathrm{C}_{3^{\prime}} \mathrm{H}\right), 3.73\left(\mathrm{dd},{ }^{2} \mathrm{~J}_{5^{\prime} \mathrm{a}, 5^{\prime} \mathrm{b}}=11.2 \mathrm{~Hz},{ }^{3} \mathrm{~J}_{5^{\prime} \mathrm{a}, 4^{\prime}}=5.7 \mathrm{~Hz}, 1 \mathrm{H}, \mathrm{C}_{5^{\prime} \mathrm{a}^{-}}\right.$ 
$\mathrm{H}), 3.62\left(\mathrm{dd},{ }^{2} J_{5^{\prime} \mathrm{a}, 5^{\prime} \mathrm{b}}=11.2 \mathrm{~Hz},{ }^{3} J^{\prime} \mathrm{b}, 4^{\prime}=6.8 \mathrm{~Hz}, 1 \mathrm{H}, \mathrm{C}_{5^{\prime} \mathrm{b}}-\mathrm{H}\right), 2.41-2.29\left(\mathrm{~m}, 1 \mathrm{H}, \mathrm{C}_{6^{\prime} \mathrm{a}}-\mathrm{H}\right), 2.28-$ $2.18\left(m, 1 \mathrm{H}, \mathrm{C}_{2^{\prime} \mathrm{a}}-\mathrm{H}\right), 2.17-2.02\left(\mathrm{~m}, 2 \mathrm{H}, \mathrm{C}_{2^{\prime} \mathrm{b}}-\mathrm{H}, \mathrm{C}_{4^{\prime} \mathrm{b}}-\mathrm{H}\right), 1.77-1.55\left(\mathrm{~m}, 1 \mathrm{H}, \mathrm{C}_{6^{\prime} \mathrm{b}}-\mathrm{H}\right)$.

${ }^{13} \mathrm{C}-\mathrm{NMR}\left(101 \mathrm{MHz}, \mathrm{CDCl}_{3}\right): \delta / \mathrm{ppm}=165.5\left(\mathrm{C}_{4}\right), 158.5\left(\mathrm{C}_{6}\right), 156.4\left(\mathrm{C}_{2}\right), 72.2\left(\mathrm{C}_{3^{\prime}}\right), 62.8\left(\mathrm{C}_{5^{\prime}}\right)$, $56.2\left(\mathrm{C}_{1^{\prime}}\right), 48.11\left(\mathrm{C}_{4^{\prime}}\right), 38.0\left(\mathrm{C}_{2^{\prime}}\right), 32.0\left(\mathrm{C}_{6^{\prime}}\right)$.

FTIR (ATR): $\tilde{v} / \mathrm{cm}^{-1}=3194(m), 1653(m), 1540(s), 1437(s), 1278(s), 1036(s)$.

\section{X-ray crystal structure analysis of cAzadC 1}

The cAzadC 1 monocrystals were analysed by X-ray crystallography (Table SI 1). The solved structure (Figure SI 1) shows the CAzadC 1 in two different Pucker conformations. Further figures were generated with the program Mercury 3.5.1. (Cambridge Crystallographic Data Center). The data are deposited under CCDC 1910952.

Table SI 1: Crystallographic data for cAzadC (9)

\begin{tabular}{|c|c|c|c|}
\hline net formula & $\mathrm{C}_{9} \mathrm{H}_{14} \mathrm{~N}_{4} \mathrm{O}_{3}$ & transmission factor range & $0.9087-0.9580$ \\
\hline $\mathrm{Mr}_{\mathrm{r}} / \mathrm{g} \mathrm{mol}^{-1}$ & 226.24 & refls. measured & 34579 \\
\hline crystal size/mm & $0.100 \times 0.080 \times 0.030$ & $R_{\text {int }}$ & 0.0373 \\
\hline$T / \mathrm{K}$ & $100(2)$ & mean $\sigma(I / /$ & 0.0197 \\
\hline radiation & MoKa & $\theta$ range & $3.031-25.40$ \\
\hline diffractometer & 'Bruker D8Venture' & observed refls. & 3474 \\
\hline crystal system & orthorhombic & $x, y$ (weighting scheme) & $0.0372,0.4868$ \\
\hline space group & 'P $212121 '$ & hydrogen refinement & mixed \\
\hline 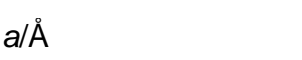 & $8.4451(3)$ & Flack parameter & $0.3(3)$ \\
\hline$b / \AA$ & $11.0958(4)$ & refls in refinement & 3787 \\
\hline$c / \AA \grave{~}$ & $21.9635(8)$ & parameters & 321 \\
\hline$\alpha /^{\circ}$ & 90 & restraints & 0 \\
\hline$\beta /^{\circ}$ & 90 & $R\left(F_{\mathrm{obs}}\right)$ & 0.0284 \\
\hline $\mathrm{y} /{ }^{\circ}$ & 90 & $R_{\mathrm{w}}\left(F^{2}\right)$ & 0.0699 \\
\hline$V / \AA^{3}$ & $2058.09(13)$ & $S$ & 1.054 \\
\hline$Z$ & 8 & shift/error $\max _{\text {m }}$ & 0.001 \\
\hline calc. density $/ \mathrm{g} \mathrm{cm}^{-3}$ & 1.460 & max electron density/e $\AA^{-3}$ & 0.180 \\
\hline$\mu / \mathrm{mm}^{-1}$ & 0.112 & min electron density/e $\AA^{-3}$ & -0.173 \\
\hline absorption correction & multi-scan & & \\
\hline
\end{tabular}


$\mathrm{C}-\mathrm{H}$ : constr, $\mathrm{O}-\mathrm{H}$ and $\mathrm{N}-\mathrm{H}$ : refall

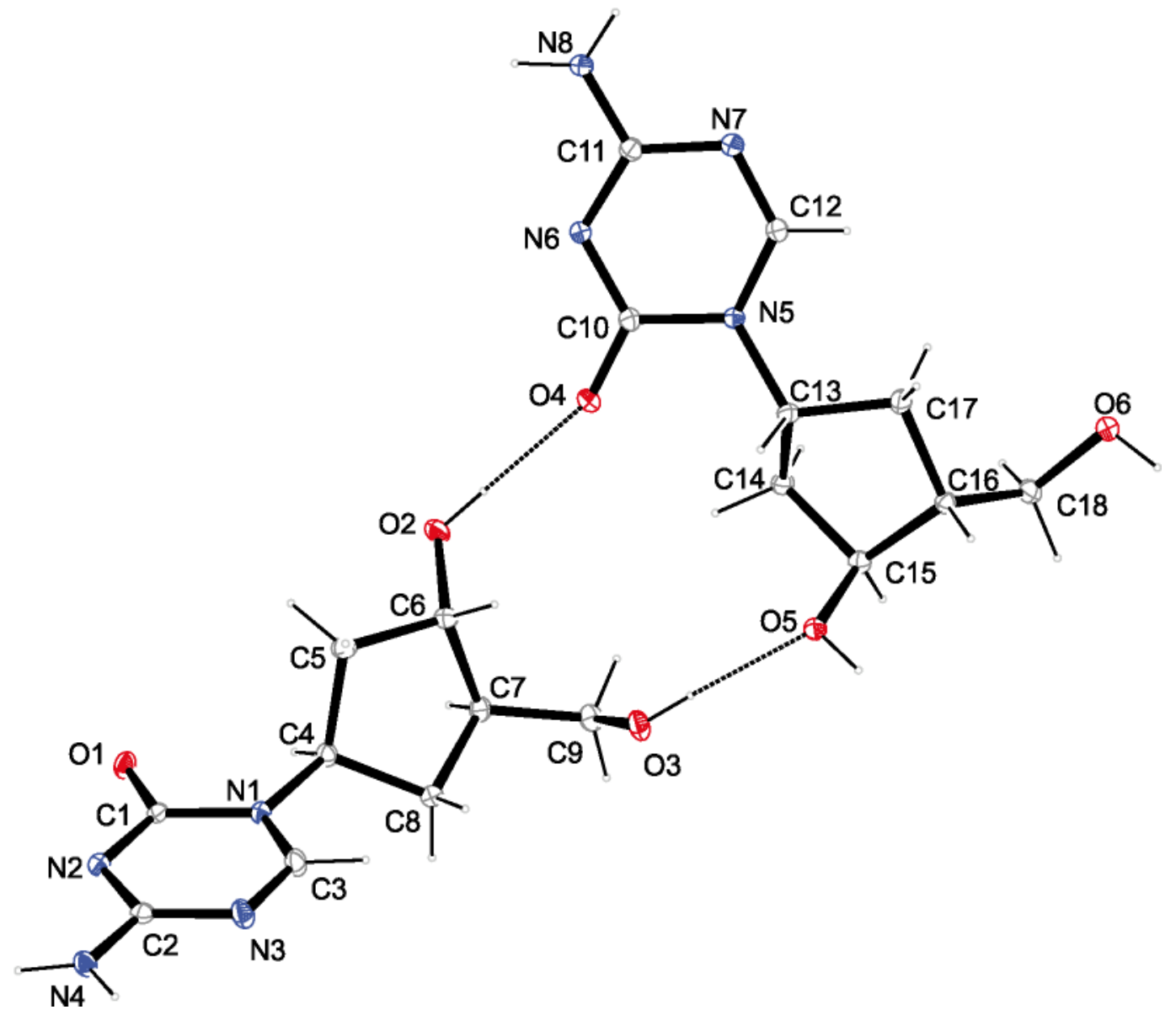

Figure SI 1: Monocrystal X-ray structure analysis of CAzadC (9) with elipsoids for the probability of presence of $50 \%$.

\section{HPLC stability analysis of cAzadC (1)}

To determine the hydrolytic stability of the carba-cyclic nucleoside cAzadC (1) in comparison with AzadC, both nucleosides were dissolved in aqueous $\mathrm{KH}_{2} \mathrm{PO}_{4}$ buffer $(100 \mathrm{mM}, \mathrm{pH}=7.4$, 5.5 and 8.5) in $100 \mathrm{mM}$ concentration. The solutions were immediately analysed via HPLC $(\mathrm{t}=0 \mathrm{~h})$ with subsequent HPLC analyses every $1.5 \mathrm{~h}$ or at indicated time points. As stationary phase an EC 250/4 NUCLEOSIL 120-3 C18 (Macherey-Nagel) chromatography column was used. The mobile phase consisted of water (buffer A) and acetonitrile (buffer B) at a flow-rate of $0.5 \mathrm{~mL} / \mathrm{min}$ as follows: $0 \rightarrow 25 \mathrm{~min}, 0 \rightarrow 5 \%$ buffer $\mathrm{B} ; 25 \mathrm{~min} \rightarrow 28 \mathrm{~min}, 5 \% \rightarrow 80 \%$; $28 \mathrm{~min} \rightarrow 38$ $\min , 80 \%$; $38 \mathrm{~min} \rightarrow 43 \mathrm{~min} 80 \% \rightarrow 0 \%$; $43 \mathrm{~min} \rightarrow 45 \mathrm{~min}, 0 \%$. 


\section{UHPLC-MS ${ }^{2}$ analysis of CAzadC (1) and calibration curves for CAzadC (1)}

UHPLC-MS ${ }^{2}$ for quantification of DNA modifications was performed as describes previously. ${ }^{[2]}$ The external calibration curve was generated by serially diluting pure cAzadC $[20$ pmol, $10 \mathrm{pmol}, 5 \mathrm{pmol}, 2.5 \mathrm{pmol}, 1.25 \mathrm{pmol}, 0.625 \mathrm{pmol}, 0.3125 \mathrm{pmol}]$ and measuring it in technical triplicates prior to each measurement. Linear regression was done by OriginPro 2016G.

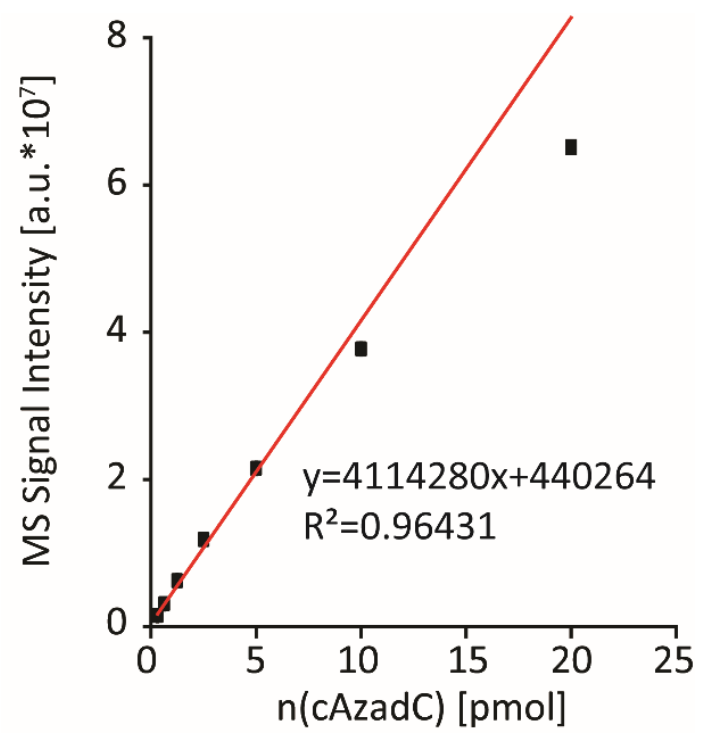

Figure SI 2: Calibration curve for carbacyclic 5-aza-2'-deoxycytidine 1 (cAzadC) quantification in genomic DNA by tandem mass spectrometry $\left(\mathrm{MS}^{2}\right)$.

[1] B. M. Domínguez, P. M. Cullis, Tetrahedron Lett. 1999, 40, 5783-5786.

[2] S. Schiffers, T. M. Wildenhof, K. Iwan, M. Stadlmeier, M. Müller, T. Carell, Helv. Chim. Acta 2019, 102, e1800229. 